\title{
REVIEW
}

\section{Genomic variants associated with primary biliary cirrhosis}

\author{
Carlo Selmi ${ }^{1,2}$, Natalie J Torok ${ }^{3}$, Andrea Affronti ${ }^{2}$ and M Eric Gershwin ${ }^{* 4}$
}

\begin{abstract}
Primary biliary cirrhosis (PBC) is an autoimmune hepatobiliary disease characterized by immunemediated injury of small and medium-sized bile ducts, eventually leading to liver cirrhosis. Several studies have addressed PBC immunopathology, and the data support an immune activation leading to autoantibodies and autoreactive $T$ cells acting against the lipoylated 2-oxoacid dehydrogenase complexes. The causes of the disease remain unknown, but environmental factors and genetic susceptibility both contribute to its onset. Over the past two decades several association studies have addressed the role of genetic polymorphisms in PBC pathogenesis and have reported multiple associations. However, only a few studies had sufficient statistical power, and in most cases results were not independently validated. A genome-wide association study has recently been reported, but this too awaits independent confirmation. The aim of this present work is to critically review the numerous studies dedicated to revealing genetic associations in PBC, and to predict the potential for future studies based on these data.
\end{abstract}

\section{Highlights of primary biliary cirrhosis}

Primary biliary cirrhosis $(\mathrm{PBC})$ is an autoimmune chronic cholestatic liver disease, histopathologically characterized by portal inflammation and immune-mediated destruction of the intrahepatic bile ducts within the portal tracts and epithelioid granulomas around damaged bile ducts. The loss of bile ducts leads to decreased bile secretion and the retention of toxic substances within the liver, resulting in further hepatic damage, fibrosis, cirrhosis and, eventually, liver failure [1]. Serologically,

*Correspondence: megershwin@ucdavis.edu

${ }^{4}$ Division of Rheumatology, Allergy and Clinical Immunology, University of California at Davis, GBSF suite 6510, 451 E. Health Sciences Dr, Davis, CA 95616, USA Full list of author information is available at the end of the article
PBC is characterized by the presence of antimitochondrial antibodies (AMAs) - which are present in 90 to 95\% of patients and are often detectable years before clinical signs appear [2]; high plasma levels of immunoglobulin M (IgM) [3]; and high-titer antibodies against nuclear antigens (ANAs). It is estimated that 30 to $50 \%$ of patients also have specific ANAs, including antibodies to nucleoporin p62 (Nup62), a glycoprotein located within the nuclear pore complex (NPC) [4]. These antibodies are associated with more severe forms of the disease. While AMA presence is often used for diagnostic purposes, ANAs and Nup62 could be linked to prognosis and are helpful tools in the management of patients with $\mathrm{PBC}$, particularly in the AMA-negative subgroup [5,6].

PBC primarily affects middle-aged women, with a female/male ratio of $9 / 1$, a characteristic shared by other autoimmune diseases [7]. It also seems to be more common among the first-degree relatives of patients $[8,9]$. Studies of the annual incidence and prevalence of $\mathrm{PBC}$ in different geographical areas suggest the impact of ethnic influences, environmental factors and the nonuniform criteria used for the diagnosis of PBC. PBC still appears to be more frequent in northern Europe and the United States, but overall the incidence ranges between 0.7 and 49 per million population, while the prevalence is between 6.7 and 402 cases per million population [10], thus making PBC a rare disease according to the 2002 Rare Disease Act. Several studies have reported a substantial increase in $\mathrm{PBC}$ prevalence and incidence over recent decades, similar to other autoimmune diseases [11]. This is mostly due to a better and earlier recognition of disease, and to more sensitive diagnostic procedures [12]. PBC is now diagnosed at an earlier stage in its clinical course than it was in the past, with 50 to $60 \%$ of patients asymptomatic at diagnosis, and one-third of them remaining symptom free for many years.

The diagnosis of PBC is currently based on three criteria: serological positivity for AMA, a cholestatic biochemical picture with elevated levels of serum alkaline phosphatase and $\gamma$ glutamyl transferase lasting for over 6 months, and histological features compatible with the presence of the disease. A probable diagnosis requires the presence of two of these three criteria, and a definite 
diagnosis requires all three. In about 5 to $10 \%$ of cases, a compatible liver biopsy together with biochemical cholestatic features of PBC but in the absence of AMA is seen. This connotes the condition known as AMA-negative $\mathrm{PBC}$ or 'autoimmune cholangiopathy', now considered a nosological entity, practically identical to $\mathrm{PBC}$ apart from the serological profile $[13,14]$. From a clinical standpoint, PBC can be divided into four stages: presymptomatic (characterized by AMA seropositivity with abnormal liver tests and without symptoms), asymptomatic (AMA seropositivity and abnormal liver tests), symptomatic (patients present PBC-related symptoms), and decompensated (symptoms and complications of end-stage liver disease).

The natural history of $\mathrm{PBC}$ is characteristically associated with important variations: while some patients present with a slowly progressive disease, others have an early onset of complications. A recent case-control study [15] showed not only that PBC is associated with other autoimmune diseases in $30 \%$ of cases (Raynaud's syndrome in $12 \%$, Sjögren syndrome in $10 \%$, rheumatoid arthritis in $10 \%$, autoimmune thyroid disease in 9\%, systemic lupus erythematosus (SLE) in 3\% and scleroderma in $2 \%$ of cases), but also that this association may be considered a negative prognostic factor. Finally, although several studies have suggested that the early use of ursodeoxycholic acid has a positive impact on prognosis, none of the current models of treatment have shown a definitive impact on the natural history of PBC [16], and at the end stage of the disease, liver transplantation is the only effective mode of treatment [17].

\section{Etiopathogenesis of PBC}

Factors leading to PBC onset remain poorly understood, but several lines of evidence suggest that immunemediated mechanisms play a crucial role. Numerous similarities exist between $\mathrm{PBC}$ and other autoimmune disorders, including female predominance, increased prevalence in subjects with a family history of $\mathrm{PBC}$, and frequent coexistence with other autoimmune diseases. The tissue selectivity of the immune attack is particular to $\mathrm{PBC}$, as is the poor responsiveness of patients to immune suppression. In addition, the breakdown of immune tolerance against mitochondrial and nuclear self-antigens is also unique to PBC.

Cholangiocytes play an important role in the pathogenesis of $\mathrm{PBC}$ and may account for the high tissue specificity. Indeed, the PBC paradox is that the damage is highly localized and only targets the lining of the small and medium-sized intrahepatic bile ducts, despite ubiquitous expression of the autoantigens [18]. The most recent data on apoptosis may provide the key to these observations [19]. Ultimately, the onset of $\mathrm{PBC}$ requires two components: a permissive genetic background and an environmental trigger. While the discussion of this latter aspect goes beyond the aims of the present article [20], we will now review the numerous studies that associate PBC onset with genetic variants and polymorphisms.

\section{Putative genomic associations in PBC}

$\mathrm{PBC}$ is more frequent in relatives of affected individuals, and the term 'familial PBC' has been coined to indicate families that have more than one case. Variable rates of familial PBC are seen in different geographical regions, possibly due to different methods of case definition. In general, data indicate that 1 to $6 \%$ of PBC cases have at least one other family member presenting with the disease [21]. Such familial prevalence rates are significantly higher than general population prevalence estimates, thus indicating a genetic predisposition to the disease. However, the difficulty of evaluating these data is that prevalence rates in the general population are still uncertain and control groups are not always included in family studies. The concordance rate observed among monozygotic twins for PBC is 63\%, among the highest reported in autoimmune diseases. This reinforces the concept of an important genetic factor in susceptibility to this disease [21], but also highlights the necessity for an environmental insult, be it chemical, bacterial, or viral [22].

Several studies have attempted to identify the genes associated with PBC. No family study of genetic linkage has been performed, possibly because $\mathrm{PBC}$ is a relatively rare disease and it is therefore difficult to obtain DNA samples from a large number of representative families. All available studies were designed in a controlled crosssectional fashion, but were prone to multiple sampling errors and biases caused by incorrect estimations. A multi-hit genetic model seems to apply to $\mathrm{PBC}$, with different genetic variants conferring susceptibility (first hit) and others influencing disease progression (second hit). For this reason, most authors investigating genetic factors in PBC have studied their role in susceptibility to the disease (comparing allele and genotype frequencies in patients and controls), as well as in its severity (through the analysis of clinical characteristics of patients carrying different genotypes or alleles). No definitive association of PBC susceptibility or progression could be identified in these studies [23]. When an association was found, it has proved to be weak or limited to specific geographical regions. We note that this also applies to the study of the variants of major histocompatibility complex (MHC; including type I, II, and III loci), in which, unlike most autoimmune diseases, reported associations were often weak [24] or limited to specific geographical areas [25]. Similar findings were also reported from the study of the genetic variants of immunomodulatory molecules (such as chemokines, receptors), enzymes producing vasoactive 
compounds, and bile-acid transporters [9]. The proposed associations are summarized next.

\section{Major histocompatibility complex and PBC}

Strong associations with specific MHC human leukocyte antigen (HLA) alleles have been reported in many autoimmune diseases, in some cases constituting the goldstandard for the diagnosis of otherwise undetermined cases [26].

Studies performed on small cohorts of subjects (between 21 and 75) have examined the association between HLA class I molecules and PBC susceptibility [27-33], but the conclusions of these early reports were affected by several major flaws, including limited statistical power, and technological problems for an accurate allele analysis. Nevertheless, our group reported that $\mathrm{PBC}$ is associated with various HLA-B alleles in a small proportion of patients [34]. It is possible that the positive association might be secondary to linkage disequilibrium. Based on the available data, we should therefore regard $\mathrm{PBC}$ associations with HLA class I genes as weak.

The association of HLA class II alleles with PBC has been widely studied in Caucasian and Asian patient cohorts. In studies from Germany, Spain, Sweden, and the United States, HLA-DR8 (DRB1*08) was found with significantly higher frequency in patients with $\mathrm{PBC}$ compared to controls; cumulatively, data aggregation indicates that $D R 8$ might constitute a risk factor for $\mathrm{PBC}$ among Caucasians [32,35-38]. In 2001, data from Newcastle, UK demonstrated that the linkage of $D Q A 1 * 0401$ and $D R 8-D Q B 1 * 0402$ is associated with PBC progression and not susceptibility [39]. Other studies in non-British European populations have not confirmed this association [30,33,34,40,41]. Moreover, other European studies suggested significant associations of $\mathrm{PBC}$ with DR3 [27,33] and DPB1*0301 [42], while the most recent study from the United States demonstrated an association between the DRB1*08-DQA1*0401-DQB1*04 haplotype and $\mathrm{PBC}$, albeit in a minority of patients [38]. Finally, studies from Japan failed to provide a consistent picture of HLA class II associations with PBC $[28,29,43]$. Interestingly, in a large series of Italian patients with $\mathrm{PBC}$ and controls, we observed a protective effect of the $D R B 1 * 11$ allele in $\mathrm{PBC}$, which was later confirmed in a larger set of patients and controls along with a positive association with DRB1*08 [25].

In summary, we can conclude that the picture of HLA class II involvement in PBC is quite complex. We could assume that, similar to the epidemiological data, the genetic background in PBC could be associated with a geographical pattern.

Data from association studies of polymorphisms of tumor necrosis factor (TNF)- $\alpha$ in $\mathrm{PBC}$ are conflicting and a cautious interpretation is encouraged [44]. A polymorphism of the gene promoter region produces the more frequent variant TNF1, and the less frequent variant TNF2 [45], with TNF2 associated with increased transcription [46-48]. The prevalence of the TNF2 allele was reportedly protective against PBC onset [49] while two other studies independently failed to detect any difference in genotype distributions between patients and controls $[50,51]$. In the study from Tanaka and colleagues, heterozygous patients had a significantly worse prognosis compared to homozygous TNF1/TNF1 patients [50], as indicated by higher Mayo score value, currently the only validated index for PBC [52]. However, a study from Newcastle, UK did not confirm this alleged association [51]. Similarly, data obtained from Scottish, Brazilian, and Chinese patient cohorts with PBC [41,53,54], and from a small population of patients undergoing liver transplantation for end-stage PBC [55], revealed no association of TNF genotypes with disease susceptibility or onset.

High-throughput novel technologies have made the study of single nucleotide polymorphisms (SNPs) of candidate genes the method of choice for association studies in PBC. The analysis of SNPs can define the linkage of specific loci or neighboring regions with disease traits. We note that, in addition to the general considerations expressed above on the choice of candidate genes and populations, the study of SNPs should be more focused on coding variants (that is, with demonstrated effects on phenotype) of genes, although this might exclude other SNPs that are possibly in linkage disequilibrium with genes that are important for disease onset [56].

\section{Non-MHC genes in PBC}

Most studies of SNPs in PBC have been dedicated to molecules involved in regulating the immune response, thus hypothesizing that genomic differences at these levels might confer susceptibility to the loss of tolerance or to an aberrant immune response. Based on the expression of cytotoxic T lymphocyte antigen-4 (CTLA-4) by $\mathrm{T}$ cells following activation and the regulatory effect of this molecule on peripheral $\mathrm{T}$ cell responses, SNPs of CTLA-4 were suggested as factors facilitating the breakdown of tolerance. Accordingly, the coding 49A $>\mathrm{G}$ SNP was found associated with PBC in a large British study [57] and in 77 Chinese patients with PBC [58], while a smaller study from Brazil failed to confirm the association [41]. Several studies were further dedicated to SNPs of interleukins (ILs), based on their critical role in the regulation of the immune response. Prompted by experimental data such as its dysregulated production by monocytes in PBC [59], SNPs of $I L-1$ were studied. First, a study from the UK reported a significantly higher frequency of the $I L-1 B * 1,1$ genotype in patients with PBC compared to controls. The difference in the $I L-1 B^{*} 1,1$ 
genotype distribution was even more marked in patients with early-stage disease, thus possibly indicating that $I L-1$ alleles might influence disease progression [39]. The lack of association with $\mathrm{PBC}$ onset was also independently confirmed by Hungarian [60] and Chinese [61] researchers. The latter group, however, more recently described an association of PBC with the IL1-RN intron genotype, comparing frequencies in 77 patients with $\mathrm{PBC}$ and 160 controls [62]. Further, based on experimental evidence of cytokine profiles and their involvement in the development of $\mathrm{T}$ helper 1 cell responses, SNPs of the promoter region of the $I L-10$ gene were also analyzed in patients with PBC and controls [53,62,63]. Data from Italian and Japanese series demonstrated that both groups presented a higher prevalence of the $-1082 \mathrm{G} / \mathrm{G}$ genotype [63]. Such association was not confirmed in 77 Chinese patients with PBC [61,62].

SNPs of the 1,25-dihydroxyvitamin D receptor (VDR) gene have been investigated in several studies, based on the dual role of vitamin $\mathrm{D}$ in the regulation of bone metabolism and inflammation. Accelerated bone loss rates in patients with prolonged cholestasis (as in PBC) have been repeatedly reported, sometimes with conflicting results, and in some cases with less than rigorous experimental designs. A significant association between BsmII polymorphisms of $V D R$ and $\mathrm{PBC}$ was reported in patients with $\mathrm{PBC}$ from Germany, Hungary, and China [60,64-66], while the proposed association with bone loss [67] was not reproduced [68]. We believe that differences in the $V D R$ gene might unravel further potential scenarios to help explain the infrequency of $\mathrm{PBC}$ in African-American women [69], and could in turn support a possible role for sunlight exposure in PBC onset. Although fascinating, this assumption remains a hypothesis, yet to be confirmed.

Molecules responsible for bile acid transport and excretion in the biliary tree have been obvious targets in the search for genomic determinants of PBC onset. Interestingly, SNPs and mutation of ATP binding cassette $(\mathrm{ABC})$ transporters involved in the secretion of bile from the hepatocyte [70] have been associated with intrahepatic cholestasis of pregnancy [71], somehow reproducing the clinical picture observed in PBC. PauliMagnus and colleagues [70] have carried out gene sequencing to investigate the variants of genes coding for the two main $\mathrm{ABC}$ transporters, identifying $45 A B C B 11$ and $46 A B C B 4$ variants, but found that no mutation was associated with PBC. More recently, a similar lack of association data was reported for the anion exchanger gene SLC4A2 [72].

Prompted by the xenobiotic PBC theory [21], we also investigated whether genetic variants leading to different xenobiotic metabolism or transport might in turn account for an increased risk of developing the disease. We therefore genotyped several polymorphisms of enzymes involved in the transport and metabolism of xenobiotics in 169 patients with PBC and 225 healthy controls [73]. Data demonstrated that no polymorphism was associated with PBC susceptibility, while a weak association of the cytochrome P450 CYP2E1 c2 allele with disease severity was observed in a small subgroup of patients.

Recent studies demonstrated that copy number variations are found in patients with $\mathrm{PBC}$, as in the case of an intragenic region on chromosome 4 called MER115. This was identified during investigation regarding microbial agents using representational difference analysis [74]. The observation that keratin mutations are more frequently encountered in $\mathrm{PBC}$ cases and reflect the disease phenotype [75] is also of note.

\section{Genome-wide studies come of age}

More recently, the first genome-wide case-control association study was reported in PBC cases from Canada and the US [76] and reported significant associations of PBC with $I L-12 A, I L-12 R B 2$, and STAT4 polymorphisms. The study benefited from sufficient statistical power due to the inclusion of 536 patients with PBC and 1,536 controls genotyped for over 300,000 SNPs, and has to be regarded as the current state-of-the-art study into the genetic basis of $\mathrm{PBC}$, although new and more powerful genotyping tools are becoming available. The role of $I L-12$ was most recently supported by experimental data from our group demonstrating in a PBC animal model that the $I L-12 p 40$ gene is crucial to autoimmunity development [77], thus proving an ideal link between genomic studies and disease pathogenesis, with potential therapeutic implications

\section{The sex chromosome connection in PBC}

Similar to other autoimmune diseases commonly diagnosed in women after the menopause [78], fetal microchimerism has been suggested in PBC, with the hypothesis of higher prevalence of small amounts of fetal (paternal) DNA found in mothers with PBC [79]. First, it was suggested that the presence of fetal DNA in the liver of affected women years after pregnancy might predispose to PBC [80]; however, independent findings have not confirmed this hypothesis $[81,82]$. Genes on the $\mathrm{X}$ chromosome are critical to the maintenance of physiological sex hormone levels and, more importantly, of immune responsiveness [83]. Invernizzi and colleagues reported age-dependent enhanced monosomy $\mathrm{X}$ in the peripheral white blood cells of women with PBC [84], and later data suggested that the $\mathrm{X}$ chromosome loss is preferential (that is, it more commonly involves the paternal or maternal chromosome) [85]. This observation seems to indicate a polygenic model for $\mathrm{PBC}$, with an $\mathrm{X}$-linked major locus of susceptibility in which genes 
escaping inactivation are the major candidates [86]. This is well represented in the recent literature on conditions characterized by major sex chromosome defects [87-90].

\section{Is it prime time for epigenetics?}

Studying the genetic basis of human diseases may yield direct data; however, uncovering the genetic causes of diseases may not help in reversing the disease process itself. In contrast, epigenetic mechanisms governing diseases seem more malleable than genetic sequences, and if causal epigenetic changes are uncovered, they may be potentially reversed through pharmacological interventions or changing environmental stimuli [91]. There is an emerging efficacy for cancer treatments in the use of 'epigenetic drugs' that inhibit DNA methylation or histone deacetylation [92], so such strategies may be useful to treat other human diseases with epigenetic bases.

Studies on the epigenetics of autoimmunity have been limited to SLE and rheumatoid arthritis, while no data are currently available for PBC [93]. In 1997, Huang and colleagues [94] failed to observe significant differences in $\mathrm{X}$ chromosome inactivation in four monozygotic twins discordant for SLE, although only one fully inactivated gene (androgen receptor) was evaluated in this work. On the other hand, Richardson and colleagues [95] demonstrated DNA hypomethylation of $\mathrm{T}$ lymphocytes of patients affected by SLE. In association with the reportedly higher numbers of CD4+ lymphocytes in females compared to males [96], these data encouraged further analysis in the field. Drugs such as hydralazine and procainamide inhibit T-cell DNA methylation and induce a murine lupus-like syndrome characterized by the presence of anti-double strand DNA (anti-dsDNA) antibodies and glomerulonephritis [97]. Recently, the effect of methylation on single molecules was demonstrated; Oelke and colleagues [98] reported the similar in vitro behavior of SLE T cells and healthy $\mathrm{T}$ cells treated with DNA methylation inhibitors. In particular, both lymphocyte populations overexpressed CD70, leading to an increased production of IgG [98]. Taken together, these findings, obtained in a different yet femalepredominant autoimmune disease such as SLE, support the potential role of epigenetics in $\mathrm{PBC}$, as represented by microRNA data [99].

\section{Concluding remarks and future developments}

Following the review of the numerous published studies on the genomic associations in $\mathrm{PBC}$, three major questions remain. Firstly, how do these new variants increase our understanding of the disease or lead to new insights about disease pathogenesis, treatment or management? This constitutes possibly the most prominent weakness of the available studies in PBC genetics, as the candidate genes were often chosen based on a weak background. This limitation can be overtaken with rigorous approaches based on solid associations, as in the case of $I L-12$. Second, how have these variants impacted on other autoimmune diseases with a genetic component? While other autoimmune diseases cannot be directly compared to $\mathrm{PBC}$, the presence of similar genetic associations between them is likely, as in the case of STAT4 in SLE and rheumatoid arthritis [100]. The third and most difficult question is related to the potential clinical applications of these variants for personalized medicine in PBC [101]. We suggest that only the integration of genomic data with findings from epigenetics and microRNA research [102], possibly through the use of antisense oligomers, will provide a pragmatic use for the gathered evidence.

\section{Abbreviations}

ABC, ATP binding cassette; AMA, antimitochondrial antibody; ANA, antinuclear antibody; CTLA-4, cytotoxic T lymphocyte antigen-4; CYP, cytochrome P450; HLA, human leukocyte antigen; IgM, immunoglobulin M; IL, interleukin; MHC, major histocompatibility complex; Nup62, nucleoporin p62; NPC, nuclear pore complex; PBC, primary biliary cirrhosis; SLE, systemic lupus erythematosus; SNP, single nucleotide polymorphism; TNF, tumor necrosis factor; VDR, 1,25-dihydroxyvitamin D receptor.

\section{Author details}

'Department of Translational Medicine, Università degli Studi di Milano, Milan, Italy

2Department of Medicine, IRCCS-Istituto Clinico Humanitas, Rozzano, Italy ${ }^{3}$ Department of Internal Medicine, Division of Gastroenterology and Hepatology, University of California, Davis, Sacramento, CA, USA ${ }^{4}$ Division of Rheumatology, Allergy and Clinical Immunology, University of California at Davis, GBSF suite 6510, 451 E. Health Sciences Dr, Davis, CA 95616, USA.

\section{Competing interests}

The authors declare that they have no competing interests.

\section{Authors' contributions}

CS performed the literature search and wrote a major part of the manuscript, NT edited the manuscript and made significant additions, AA contributed to the literature search and data discussion, MEG mentored the co-authors and contributed to the manuscript writing.

Published: 26 January 2010

\section{References}

1. Kaplan MM, Gershwin ME: Primary biliary cirrhosis. N Engl J Med 2005, 353:1261-1273.

2. Selmi C, Zuin M, Bowlus CL, Gershwin ME: Anti-mitochondrial antibodynegative primary biliary cirrhosis. Clin Liver Dis 2008, 12:173-185, ix.

3. Kikuchi K, Lian ZX, Yang GX, Ansari AA, Ikehara S, Kaplan M, Miyakawa H, Coppel RL, Gershwin ME: Bacterial CpG induces hyper-IgM production in CD27(+) memory B cells in primary biliary cirrhosis. Gastroenterology 2005, 128:304-312.

4. Invernizzi P, Selmi C, Ranftler C, Podda M, Wesierska-Gadek J: Antinuclear antibodies in primary biliary cirrhosis. Semin Liver Dis 2005, 25:298-310.

5. Wesierska-Gadek J, Penner E, Battezzati PM, Selmi C, Zuin M, Hitchman E, Worman HJ, Gershwin ME, Podda M, Invernizzi P: Correlation of initial autoantibody profile and clinical outcome in primary biliary cirrhosis. Hepatology 2006, 43:1135-1144.

6. Nakamura M, Shimizu-Yoshida Y, Takii Y, Komori A, Yokoyama T, Ueki T, Daikoku M, Yano K, Matsumoto T, Migita K, Yatsuhashi H, Ito M, Masaki N, Adachi H, Watanabe Y, Nakamura Y, Saoshiro T, Sodeyama T, Koga M, Shimoda S, Ishibashi $\mathrm{H}$ : Antibody titer to gp210-C terminal peptide as a clinical parameter for monitoring primary biliary cirrhosis. J Hepatol 2005, 42:386-392. 
7. Lleo A, Battezzati PM, Selmi C, Gershwin ME, Podda M: Is autoimmunity a matter of sex? Autoimmun Rev 2008, 7:626-630.

8. Jones DE, Watt FE, Metcalf JV, Bassendine MF, James OF: Familial primary biliary cirrhosis reassessed: a geographically-based population study. $J$ Hepatol 1999, 30:402-407.

9. Invernizzi P, Gershwin ME: The genetic basis of primary biliary cirrhosis: premises, not promises. Gastroenterology 2008, 135:1044-1047.

10. Lazaridis KN, Talwalkar JA: Clinical epidemiology of primary biliary cirrhosis: incidence, prevalence, and impact of therapy. J Clin Gastroenterol 2007, 41:494-500

11. Cooper GS, Bynum ML, Somers EC: Recent insights in the epidemiology of autoimmune diseases: Improved prevalence estimates and understanding of clustering of diseases. J Autoimmun 2009, 33:197-207.

12. Selmi C, Invernizzi P, Zuin M, Podda M, Gershwin ME: Genetics and geoepidemiology of primary biliary cirrhosis: following the footprints to disease etiology. Semin Liver Dis 2005, 25:265-280.

13. Invernizzi P, Crosignani A, Battezzati PM, Covini G, De Valle G, Larghi A, Zuin M, Podda M: Comparison of the clinical features and clinical course of antimitochondrial antibody-positive and -negative primary biliary cirrhosis. Hepatology 1997, 25:1090-1095.

14. Shimoda S, Harada K, Niiro H, Yoshizumi T, Soejima Y, Taketomi A, Maehara Y, Tsuneyama K, Nakamura M, Komori A, Migita K, Nakanuma Y, Ishibashi H, Selmi C, Gershwin ME: Biliary epithelial cells and primary biliary cirrhosis: The role of liver-infiltrating mononuclear cells. Hepatology 2008, 47:958-965

15. Gershwin ME, Selmi C, Worman HJ, Gold EB, Watnik M, Utts J, Lindor KD, Kaplan MM, Vierling JM: Risk factors and comorbidities in primary biliary cirrhosis: a controlled interview-based study of 1032 patients. Hepatology 2005, 42:1194-1202

16. Gong Y, Huang ZB, Christensen E, Gluud C: Ursodeoxycholic acid for primary biliary cirrhosis. Cochrane Database Syst Rev 2008, 3:CD000551.

17. Neuberger J: Liver transplantation for primary biliary cirrhosis: indications and risk of recurrence. J Hepato/ 2003, 39:142-148.

18. Gershwin ME, Mackay IR, Sturgess A, Coppel RL: Identification and specificity of a cDNA encoding the $70 \mathrm{kd}$ mitochondrial antigen recognized in primary biliary cirrhosis. J Immunol 1987, 138:3525-3531.

19. Lleo A, Selmi C, Invernizzi P, Podda M, Coppel RL, Mackay IR, Gores GJ, Ansar AA, Van de Water J, Gershwin ME: Apotopes and the biliary specificity of primary biliary cirrhosis. Hepatology 2009, 49:871-879.

20. Agmon-Levin N, Ram M, Barzilai O, Porat-Katz BS, Parikman R, Selmi C, Gershwin ME, Anaya JM, Youinou P, Bizzaro N, Tincani A, Tzioufas AG, Cervera R, Stojanovich L, Martin J, Gonzalez-Gay MA, Valentini G, Blank M, SanMarco M, Rozman B, Bombardieri S, De Vita S, Shoenfeld Y: Prevalence of hepatitis C serum antibody in autoimmune diseases. J Autoimmun 2009, 32:261-266.

21. Selmi C, Invernizzi P, Keefe EB, Coppel RL, Podda M, Rossaro L, Ansari AA Gershwin ME: Epidemiology and pathogenesis of primary biliary cirrhosis. Clin Gastroentero/ 2004, 38:264-271.

22. Christen $\mathrm{U}$, Hintermann $\mathrm{E}$, Holdener $\mathrm{M}$, von Herrath MG: Viral triggers for autoimmunity: Is the 'glass of molecular mimicry' half full or half empty? J Autoimmun 2009. [Epub ahead of print]

23. Jones DE, Donaldson PT: Genetic factors in the pathogenesis of primary biliary cirrhosis. Clin Liver Dis 2003, 7:841-864.

24. Invernizzi P, Selmi C, Mackay IR, Podda M, Gershwin ME: From bases to basis: linking genetics to causation in primary biliary cirrhosis. Clin Gastroenterol Hepatol 2005, 3:401-410

25. Invernizzi P, Selmi C, Poli F, Frison S, Floreani A, Alvaro D, Almasio P, Rosina F, Marzioni M, Fabris L, Muratori L, Oi L, Seldin MF, Gershwin ME, Podda M: Human leukocyte antigen polymorphisms in Italian primary biliary cirrhosis: a multicenter study of 664 patients and 1992 healthy controls. Hepatology 2008, 48:1906-1912

26. McCluskey J, Peh CA: The human leucocyte antigens and clinical medicine: an overview. Rev /mmunogenet 1999, 1:3-20

27. Ercilla G, Parés A, Arriaga F, Bruguera M, Castillo R, Rodés J, Vives J: Primary biliary cirrhosis associated with DLA-DRw3. Tissue Antigens 1979. 14:449-452.

28. Miyamori H, Kato Y, Kobayashi K, Hattori N: HLA antigens in Japanese patients with primary biliary cirrhosis and autoimmune hepatitis. Digestion 1983, 26:213-217

29. Onishi S, Sakamaki T, Maeda T, Iwamura S, Tomita A, Saibara T, Yamamoto Y: DNA typing of HLA class II genes; DRB1*0803 increases the susceptibility of Japanese to primary biliary cirrhosis. J Hepatol 1994, 21:1053-1060.
30. Bassendine MF, Dewar PJ, James OF: HLA-DR antigens in primary biliary cirrhosis: lack of association. Gut 1985, 26:625-628.

31. Briggs DC, Donaldson PT, Hayes P, Welsh KI, Williams R, Neuberger JM: A major histocompatibility complex class III allotype (C4B 2) associated with primary biliary cirrhosis (PBC). Tissue Antigens 1987, 29:141-145.

32. Manns MP, Bremm A, Schneider PM, Notghi A, Gerken G, Prager-Eberle M, Stradmann-Bellinghausen B, Meyer zum Buschenfelde KH, Rittner C: HLA DRw8 and complement C4 deficiency as risk factors in primary biliary cirrhosis. Gastroenterology 1991, 101:1367-1373.

33. Morling N, Dalhoff K, Fugger L, Georgsen J, Jakobsen B, Ranek L, Odum N, Svejgaard A: DNA polymorphism of HLA class II genes in primary biliary cirrhosis. Immunogenetics 1992, 35:112-116.

34. Invernizzi P, Battezzati PM, Crosignani A, Perego F, Poli F, Morabito A, De Arias AE, Scalamogna M, Zuin M, Podda M: Peculiar HLA polymorphisms in Italian patients with primary biliary cirrhosis. J Hepatol 2003, 38:401-406.

35. Gores GJ, Moore SB, Fisher LD, Powell FC, Dickson ER: Primary biliary cirrhosis: associations with class II major histocompatibility complex antigens. Hepatology 1987, 7:889-892.

36. Begovich AB, Klitz W, Moonsamy PV, Van de Water J, Peltz G, Gershwin ME: Genes within the HLA class II region confer both predisposition and resistance to primary biliary cirrhosis. Tissue Antigens 1994, 43:71-77.

37. Wassmuth R, Depner F, Danielsson A, Hultcrantz R, Loof L, Olson R, Prytz H, Sandberg-Gertzen H, Wallerstedt S, Lindgren S: HLA class II markers and clinical heterogeneity in Swedish patients with primary biliary cirrhosis. Tissue Antigens 2002, 59:381-387.

38. Mullarkey ME, Stevens AM, McDonnell WM, Loubiere LS, Brackensick JA, Pang JM, Porter AJ, Galloway DA, Nelson JL: Human leukocyte antigen class II alleles in Caucasian women with primary biliary cirrhosis. Tissue Antigens 2005, 65:199-205.

39. Donaldson P, Agarwal K, Craggs A, Craig W, James O, Jones D: HLA and interleukin 1 gene polymorphisms in primary biliary cirrhosis: associations with disease progression and disease susceptibility. Gut 2001, 48:397-402.

40. Zhang L, Weetman AP, Bassendine M, Oliveira DB: Major histocompatibility complex class-II alleles in primary biliary cirrhosis. Scand J Immunol 1994, 39:104-106.

41. Bittencourt PL, Palacios SA, Farias AQ, Abrantes-Lemos CP, Cancado EL, Carrilho FJ, Laudanna AA, Kalil J, Goldberg AC: Analysis of major histocompatibility complex and CTLA-4 alleles in Brazilian patients with primary biliary cirrhosis. J Gastroenterol Hepatol 2003, 18:1061-1066

42. Mella JG, Roschmann E, Maier KP, Volk BA: Association of primary biliary cirrhosis with the allele HLA-DPB1*0301 in a German population. Hepatology 1995, 21:398-402.

43. Seki T, Kiyosawa K, Ota M, Furuta S, Fukushima H, Tanaka E, Yoshizawa K, Kumagai T, Mizuki N, Ando A, et al.: Association of primary biliary cirrhosis with human leukocyte antigen DPB $1 * 0501$ in Japanese patients. Hepatology 1993, 18:73-78.

44. Donaldson PT: TNF gene polymorphisms in primary biliary cirrhosis: a critical appraisal. J Hepatol 1999, 31:366-368.

45. Wilson AG, di Giovine FS, Blakemore Al, Duff GW: Single base polymorphism in the human tumour necrosis factor alpha (TNF alpha) gene detectable by Ncol restriction of PCR product. Hum Mol Genet 1992, 1:353.

46. Wilson AG, Symons JA, McDowell TL, McDevitt HO, Duff GW: Effects of a polymorphism in the human tumor necrosis factor alpha promoter on transcriptional activation. Proc Natl Acad Sci U S A 1997, 94:3195-3199.

47. Kroeger KM, Carville KS, Abraham LJ: The -308 tumor necrosis factor-alpha promoter polymorphism effects transcription. Mol Immunol 1997, 34:391-399.

48. Wu WS, McClain KL: DNA polymorphisms and mutations of the tumor necrosis factor-alpha (TNF-alpha) promoter in Langerhans cell histiocytosis (LCH). J Interferon Cytokine Res 1997, 17:631-635.

49. Gordon MA, Oppenheim E, Camp NJ, di Giovine FS, Duff GW, Gleeson D: Primary biliary cirrhosis shows association with genetic polymorphism of tumour necrosis factor alpha promoter region. [see comments] $\mathrm{J}$ Hepatol 1999, 31:242-247.

50. Tanaka A, Quaranta S, Mattalia A, Coppel R, Rosina F, Manns M, Gershwin ME: The tumor necrosis factor-alpha promoter correlates with progression of primary biliary cirrhosis. J Hepato/ 1999, 30:826-829.

51. Jones DE, Watt FE, Grove J, Newton JL, Daly AK, Gregory WL, Day CP, James OF, Bassendine MF: Tumour necrosis factor-alpha promoter polymorphisms in primary biliary cirrhosis. [see comments] J Hepatol 1999, 30:232-236.

52. Dickson ER, Grambsch PM, Fleming TR, Fisher LD, Langworthy A: Prognosis in 
primary biliary cirrhosis: model for decision making. Hepatology 1989, 10:1-7.

53. Bathgate AJ, Pravica V, Perrey C, Hayes PC, Hutchinson IV: Polymorphisms in tumour necrosis factor alpha, interleukin-10 and transforming growth factor beta1 genes and end-stage liver disease. Eur J Gastroenterol Hepatol 2000, 12:1329-1333.

54. Fan LY, Zhong RQ, Tu XQ, Thomas P, Ralph F, Zhu Y, Zhou L: [Genetic association of tumor necrosis factor (TNF)-alpha polymorphisms with primary biliary cirrhosis and autoimmune liver diseases in a Chinese population]. Zhonghua Gan Zang Bing Za Zhi 2004, 12:160-162.

55. Jazrawi SF, Zaman A, Muhammad Z, Rabkin JM, Corless CL, Olyaei A, Biggs A, Ham J, Chou S, Rosen HR: Tumor necrosis factor-alpha promoter polymorphisms and the risk of rejection after liver transplantation: a case control analysis of 210 donor-recipient pairs. Liver Transp/ 2003, 9:377-382.

56. Hirschhorn JN, Lohmueller K, Byrne E, Hirschhorn K: A comprehensive review of genetic association studies. Genet Med 2002, 4:45-61.

57. Agarwal K, Jones DE, Daly AK, James OF, Vaidya B, Pearce S, Bassendine MF: CTLA-4 gene polymorphism confers susceptibility to primary biliary cirrhosis. J Hepatol 2000, 32:538-541

58. Fan LY, Tu XQ, Cheng QB, Zhu Y, Feltens R, Pfeiffer T, Zhong RQ: Cytotoxic T lymphocyte associated antigen-4 gene polymorphisms confer susceptibility to primary biliary cirrhosis and autoimmune hepatitis in Chinese population. World J Gastroenterol 2004, 10:3056-3059.

59. Kershenobich D, Rojkind M, Quiroga A, Alcocer-Varela J: Effect of colchicine on lymphocyte and monocyte function and its relation to fibroblast proliferation in primary biliary cirrhosis. Hepatology 1990, 11:205-209.

60. Lakatos LP, Bajnok E, Hegedus D, Toth T, Lakatos P, Szalay F: Vitamin D receptor, oestrogen receptor-alpha gene and interleukin-1 receptor antagonist gene polymorphisms in Hungarian patients with primary biliary cirrhosis. Eur J Gastroenterol Hepatol 2002, 14:733-740.

61. Fan LY, Zhu Y, Zhong RQ, Tu XQ, Ye WM, Chen QB, Zeng WJ, Kong XT: [Genetic association between interleukins gene polymorphisms with primary biliary cirrhosis in Chinese population]. Zhongguo Yi Xue Ke Xue Yuan Xue Bao 2004, 26:505-509.

62. Fan $L Y$, Tu XQ, Zhu Y, Pfeiffer T, Feltens R, Stoecker W, Zhong RQ: Genetic association of cytokines polymorphisms with autoimmune hepatitis and primary biliary cirrhosis in the Chinese. World J Gastroenterol 2005, 11:2768-2772.

63. Matsushita M, Tanaka A, Kikuchi K, Kitazawa E, Kawaguchi N, Kawashima Y, Kato T, Fujikawa H, Quaranta S, Rosina F, Gershwind ME, Miyakawa H: Association of single nucleotide polymorphisms of the interleukin-10 promoter gene and susceptibility to primary biliary cirrhosis: immunogenetic differences in Italian and Japanese patients. Autoimmunity 2002, 35:531-536.

64. Vogel A, Strassburg CP, Manns MP: Genetic association of vitamin D receptor polymorphisms with primary biliary cirrhosis and autoimmune hepatitis. Hepatology 2002, 35:126-131.

65. Halmos B, Szalay F, Cserniczky T, Nemesanszky E, Lakatos P, Barlage S, Schmitz $G$, Romics L, Csaszar A: Association of primary biliary cirrhosis with vitamin $D$ receptor Bsml genotype polymorphism in a Hungarian population. Dig Dis Sci 2000, 45:1091-1095.

66. Fan $L Y$, Zhong RQ, Tu XQ, Zhu Y, Gong CL, Zhou L, Zhao ZX, Feltens R, Pfeiffer $\mathrm{T}$ : [Genetic association of vitamin $\mathrm{D}$ receptor polymorphisms with primary biliary cirrhosis and autoimmune liver diseases on Chinese]. Zhonghua Yi Xue Za Zhi 2003, 83:1852-1855.

67. Springer JE, Cole DE, Rubin LA, Cauch-Dudek K, Harewood L, Evrovski J, Peltekova VD, Heathcote EJ: Vitamin D-receptor genotypes as independent genetic predictors of decreased bone mineral density in primary biliary cirrhosis. Gastroenterology 2000, 118:145-151.

68. Pares A, Guanabens N, Alvarez L, De Osaba MJ, Oriola J, Pons F, Caballeria L, Monegal A, Salvador G, Jo J, Peris P, Rivera F, Ballesta AM, Rodes J: Collagen type lalpha1 and vitamin $D$ receptor gene polymorphisms and bone mass in primary biliary cirrhosis. Hepatology 2001, 33:554-560.

69. Vong S, Bell BP: Chronic liver disease mortality in the United States, 19901998. Hepatology 2004, 39:476-483.

70. Pauli-Magnus C, Kerb R, Fattinger K, Lang T, Anwald B, Kullak-Ublick GA, Beuers U, Meier PJ: BSEP and MDR3 haplotype structure in healthy Caucasians, primary biliary cirrhosis and primary sclerosing cholangitis. Hepatology 2004, 39:779-791.

71. Pauli-Magnus C, Lang T, Meier Y, Zodan-Marin T, Jung D, Breymann C, Zimmermann R, Kenngott S, Beuers U, Reichel C, Kerb R, Penger A, Meier PJ,
Kullak-Ublick GA: Sequence analysis of bile salt export pump (ABCB11) and multidrug resistance $p$-glycoprotein 3 ( $A B C B 4, M D R 3)$ in patients with intrahepatic cholestasis of pregnancy. Pharmacogenetics 2004, 14:91-102.

72. Juran BD, Atkinson EJ, Larson JJ, Schlicht EM, Lazaridis KN: Common genetic variation and haplotypes of the anion exchanger SLC4A2 in primary biliary cirrhosis. Am J Gastroenterol 2009, 104:1406-1411.

73. Kimura Y, Selmi C, Leung PS, Mao TK, Schauer J, Watnik M, Kuriyama S, Nishioka M, Ansari AA, Coppel RL, Invernizzi P, Podda M, Gershwin ME: Genetic polymorphisms influencing xenobiotic metabolism and transport in patients with primary biliary cirrhosis. Hepatology 2005, 41:55-63.

74. Xu L, Guo L, Shen Z, Loss G, Gish R, Wasilenko S, Mason AL: Duplication of MER115 on chromosome 4 in patients with primary biliary cirrhosis. Liver Int 2009, 29:375-383.

75. Zhong B, Strnad P, Selmi C, Invernizzi P, Tao GZ, Caleffi A, Chen M, Bianchi I, Podda M, Pietrangelo A, Gershwin ME, Omary MB: Keratin variants are overrepresented in primary biliary cirrhosis and associate with disease severity. Hepatology 2009, 50:546-554.

76. Hirschfield GM, Liu X, Xu C, Lu Y, Xie G, Gu X, Walker EJ, Jing K, Juran BD, Mason AL, Myers RP, Peltekian KM, Ghent CN, Coltescu C, Atkinson EJ, Heathcote EJ, Lazaridis KN, Amos Cl, Siminovitch KA: Primary biliary cirrhosis associated with HLA, IL12A, and IL12RB2 variants. N Engl J Med 2009, 360:2544-2555.

77. Yoshida K, Yang GX, Zhang W, Tsuda M, Tsuneyama K, Moritoki Y, Ansari AA, Okazaki K, Lian ZX, Coppel RL, Mackay IR, Gershwin ME: Deletion of interleukin-12p40 suppresses autoimmune cholangitis in dominant negative transforming growth factor beta receptor type II mice. Hepatology 2009, 50:1494-1500.

78. Lambert N, Nelson JL: Microchimerism in autoimmune disease: more questions than answers? Autoimmun Rev 2003, 2:133-139.

79. Sarkar K, Miller FW: Possible roles and determinants of microchimerism in autoimmune and other disorders. Autoimmun Rev 2004, 3:454-463.

80. Fanning PA, Jonsson JR, Clouston AD, Edwards-Smith C, Balderson GA, Macdonald GA, Crawford DH, Kerlin P, Powell LW, Powell EE: Detection of male DNA in the liver of female patients with primary biliary cirrhosis. J Hepatol 2000, 33:690-695.

81. Tanaka A, Lindor K, Gish R, Batts K, Shiratori Y, Omata M, Nelson JL, Ansari A, Coppel R, Newsome M, Gershwin ME: Fetal microchimerism alone does not contribute to the induction of primary biliary cirrhosis. Hepatology 1999, 30:833-838.

82. Invernizzi P, De Andreis C, Sirchia SM, Battezzati PM, Zuin M, Rossella F, Perego F, Bignotto M, Simoni G, Podda M: Blood fetal microchimerism in primary biliary cirrhosis. Clin Exp Immunol 2000, 122:418-422.

83. Invernizzi P, Pasini S, Selmi C, Gershwin ME, Podda M: Female predominance and $\mathrm{X}$ chromosome defects in autoimmune diseases. J Autoimmun 2009, 33:12-16.

84. Invernizzi P, Miozzo M, Battezzati PM, Bianchi I, Grati FR, Simoni G, Selmi C, Watnik M, Gershwin ME, Podda M: Frequency of monosomy X in women with primary biliary cirrhosis. Lancet 2004, 363:533-535.

85. Miozzo M, Selmi C, Gentilin B, Grati FR, Sirchia S, Oertelt S, Zuin M, Gershwin ME, Podda M, Invernizzi P: Preferential X chromosome loss but random inactivation characterize primary biliary cirrhosis. Hepatology 2007, 46:456-462.

86. Lleo A, Selmi C, Invernizzi P, Podda M, Gershwin ME: The consequences of apoptosis in autoimmunity. J Autoimmun 2008, 31:257-262.

87. Larizza D, Calcaterra V, Martinetti M: Autoimmune stigmata in Turner syndrome: when lacks an X chromosome. J Autoimmun 2009, 33:25-30

88. Persani L, Rossetti R, Cacciatore C, Bonomi M: Primary ovarian insufficiency: X chromosome defects and autoimmunity. J Autoimmun 2009, 33:35-41.

89. Pessach IM, Notarangelo LD: X-linked primary immunodeficiencies as a bridge to better understanding $X$-chromosome related autoimmunity. J Autoimmun 2009, 33:17-24

90. Sawalha AH, Harley JB, Scofield RH: Autoimmunity and Klinefelter's syndrome: when men have two X chromosomes. J Autoimmun 2009, 33:31-34

91. Sanchez-Pernaute O, Ospelt C, Neidhart M, Gay S: Epigenetic clues to rheumatoid arthritis. J Autoimmun 2008, 30:12-20.

92. Egger $\mathrm{G}$, Liang $\mathrm{G}$, Aparicio A, Jones PA: Epigenetics in human disease and prospects for epigenetic therapy. Nature 2004, 429:457-463.

93. Hewagama A, Richardson B: The genetics and epigenetics of autoimmune diseases. J Autoimmun 2009, 33:3-11.

94. Huang Q, Parfitt A, Grennan DM, Manolios N: X-chromosome inactivation in 
monozygotic twins with systemic lupus erythematosus. Autoimmunity 1997, 26:85-93.

95. Richardson B, Scheinbart L, Strahler J, Gross L, Hanash S, Johnson M: Evidence for impaired T cell DNA methylation in systemic lupus erythematosus and rheumatoid arthritis. Arthritis Rheum 1990, 33:1665-1673.

96. Amadori A, Zamarchi R, De Silvestro G, Forza G, Cavatton G, Danieli GA, Clementi M, Chieco-Bianchi L: Genetic control of the CD4/CD8 T-cell ratio in humans. Nat Med 1995, 1:1279-1283.

97. Quddus J, Johnson KJ, Gavalchin J, Amento EP, Chrisp CE, Yung RL, Richardson BC: Treating activated CD4+ T cells with either of two distinct DNA methyltransferase inhibitors, 5-azacytidine or procainamide, is sufficient to cause a lupus-like disease in syngeneic mice. J Clin Invest 1993, 92:38-53.

98. Oelke K, Lu Q, Richardson D, Wu A, Deng C, Hanash S, Richardson B: Overexpression of CD70 and overstimulation of lgG synthesis by lupus T cells and T cells treated with DNA methylation inhibitors. Arthritis Rheum 2004, 50:1850-1860.

99. Padgett KA, Lan RY, Leung PC, Lleo A, Dawson K, Pfeiff J, Mao TK, Coppel RL,
Ansari AA, Gershwin ME: Primary biliary cirrhosis is associated with altered hepatic microRNA expression. J Autoimmun 2009, 32:246-253.

100. Remmers EF, Plenge RM, Lee AT, Graham RR, Hom G, Behrens TW, de Bakker PI, Le JM, Lee HS, Batliwalla F, Li W, Masters SL, Booty MG, Carulli JP, Padyukov L, Alfredsson L, Klareskog L, Chen WV, Amos Cl, Criswell LA, Seldin MF, Kastner DL, Gregersen PK: STAT4 and the risk of rheumatoid arthritis and systemic lupus erythematosus. N Engl J Med 2007, 357:977-986.

101. Invernizzi P, Gershwin ME: The genetics of human autoimmune disease. J Autoimmun 2009, 33:290-299.

102. Pauley KM, Cha S, Chan EK: MicroRNA in autoimmunity and autoimmune diseases. J Autoimmun 2009, 32:189-194.

doi:10.1186/gm126

Cite this article as: Selmi C, et al:: Genomic variants associated with primary biliary cirrhosis. Genome Medicine 2010, 2:5. 